\title{
Digitalization of agricultural sector of the Russian Federation: features and development trends
}

\author{
Anna Kulik $^{1, *}$ Natalya Gerasimova ${ }^{1}$, Natalya Kalutskaya ${ }^{2}$, Elena Druznikova ${ }^{1}$, Munoz \\ Andrade Luis Fernando 3 \\ ${ }^{1}$ Department of Applied Economics and Economic Security, Belgorod State University, Belgorod, \\ Russia \\ ${ }^{2}$ Department of Innovative Economics and Finance, Belgorod State University, Belgorod, Russia \\ ${ }^{3}$ Russian University, Quito, Ecuador.
}

\begin{abstract}
Currently, the economies of most developed countries in the world are at the stage of digital transformation. Daily streams of information data contain various innovations, nanotechnologies, business projects, and know-hows. Smart technologies are turning out to be faster, more compact, more efficient, and more powerful every year and are becoming the key to solving problems in various fields of activity. The agricultural sector is no exception. Over the past decade, the agroindustrial complex has undergone numerous changes as part of government projects on implementation of IT systems designed to solve a wide range of tasks, to search for new technologies of manufacturing environmentally friendly and safe products, thereby expanding possibilities for the agricultural market to enter a new level of international trade.
\end{abstract}

\section{Introduction}

One of the first English-language works devoted to the digital economy was a book by D. Tapscott 'The Digital Economy: Promise and Peril in the Age of Networked Intelligence', published in 1996 (and republished in 2015). The author paid attention to the new opportunities for society to combine knowledge and creativity. In 2002, a collection of papers presented at a conference held at the US Department of Commerce in May 1999 entitled 'Understanding the Digital Economy' was published. The authors of the reports assessed the current state of research in this area at that time, investigated the changes that affected both individual business units and the structure of the economy (including the labor market) as a whole.

Among modern English-language works, it is worth noting the book by T. Scholz, published in 2017, entitled 'Uberworked and Underpaid: How Workers Are Disrupting the Digital Economy' focusing on the challenges of the workforce employed by digital giants such as Uber and Amazon.

\footnotetext{
*Corresponding author: kulik@bsu.edu.ru
} 
It is also worth noting the publication by B. Van Ark (2016), which points to the fact that the new digital economy has not yet led to a noticeable increase in productivity according to the author, it is still in the 'setup stage', while productivity effects can only occur when the technology enters the 'deployment stage'.

Several general studies have been carried out, in which digital economy is considered as a new stage in the economy development. These are, for example, the works by S.A. Zhironkin (2015) (digitalization is presented as a way to overcome degenerative processes in the domestic economy), N.I. Antipina (2018) (description of the transformation of Russian business in a new era), K.A. Semyachkova (2018) (changes in the public sector caused by digital economy), etc.

Some authors prefer to focus on specific technological solutions accompanying transition of the economy to a new stage. One can talk, for example, about blockchain technology (Nurmukhametov R.K., Stepanov P.D., Novikova T.R., 2017) or about building a conceptual architecture of the digital industry ecosystem (Akatkin Yu.M., Karpov O.E., Konyavskiy V.A., Yasinovskaya E.D., 2017).

The works of Shuyun G., Din V., Lanshina T. (2017) and Smorodinskaya N.V., Katukova D.D. (2017) are devoted to the international experience of managing digital economy, as well as globalization - a process parallel to digitalization, directly related to the latter.

Finally, a significant array of scientific works is devoted to the problems of personnel training in digital economy, as well as characteristics of the labor market in a new era (for example, Kashinskaya I.V., Korovkina N.L., Lyovochkina G.A., 2018). The impact of digitalization on university education system is discussed, in particular, by Shashlo N.V., Petruk G.V. (2017), Efimov V.S., Lapteva A.V. (2018), Bolgova E.V., Grodskaya G N., Kournikova M.V. (2019).

\section{Background}

Digital transformations, digitalization of all types of activity and the related spread of resources - information, telecommunication, digital - are now becoming widespread in all regions of the Russian Federation. That is, digitalization resources are currently becoming the most significant factor in society development, they affect all types of activities and their competent use leads to an increase in the efficiency of any industry.

Turning to the definition of the term digital economy, it can be emphasized that there is no common opinion on the identification of the term 'digital economy', the question of what this definition implies is debatable. Most researchers are of the opinion that the term 'digital economy' was correctly interpreted by D. Tapscott, a Canadian scientist, who in 1994 in his book 'Digital Economy' gives the concept of this definition as: 'an economy based on digital technologies' [1].

When identifying this concept, researchers adhere to a basic approach that represents digital economy as economy based on production of goods and services by high-tech business structures and sale of these products through the use of e-commerce tools [2]. The author's approach is interesting, as it defines digital economy (electronic economy) through its characteristic features, which consist in the maximum satisfaction of the needs of all its participants through the use of information, including personal information. This becomes possible thanks to the development of information, communication and financial technologies, as well as availability of infrastructure, which together provide the possibility of full interaction in the hybrid world of all participants in economic activity: subjects and objects of creation, distribution, exchange and consumption of goods and services [4].

The concept of 'digital economy' is also identified with a certain set of economic and social activities. These activities are carried out through the use of information and 
communication technologies (Internet, mobile and sensor networks). This also includes the processes of communications, financial transactions, education, entertainment and other types of business with the active use of devices such as computers, smartphones and others $[5]$.

Official documents also interpret the concept of 'digital economy' in the same way. Such documents include the 'Strategy for the Development of Information Society in the Russian Federation for 2017-2030', where digital economy is interpreted as 'an economic order characterized by transition to a qualitatively new level of use of information and telecommunication technologies in all spheres of socio-economic activity' [6 ].

We believe that digital economy presupposes digital transformations. The essence of digital transformations lies in the transition of socio-economic systems of various kinds to the massive use of all kinds of digital technologies [7].

Considering the rating of digital competitiveness of countries, it can be concluded that at present Russia has a significant lag from the leading digitalization countries, which include Finland, Switzerland, the USA, Singapore and some others. The Russian Federation was in 38th place in 2019, according to the rating of digital competitiveness (Figure 1).

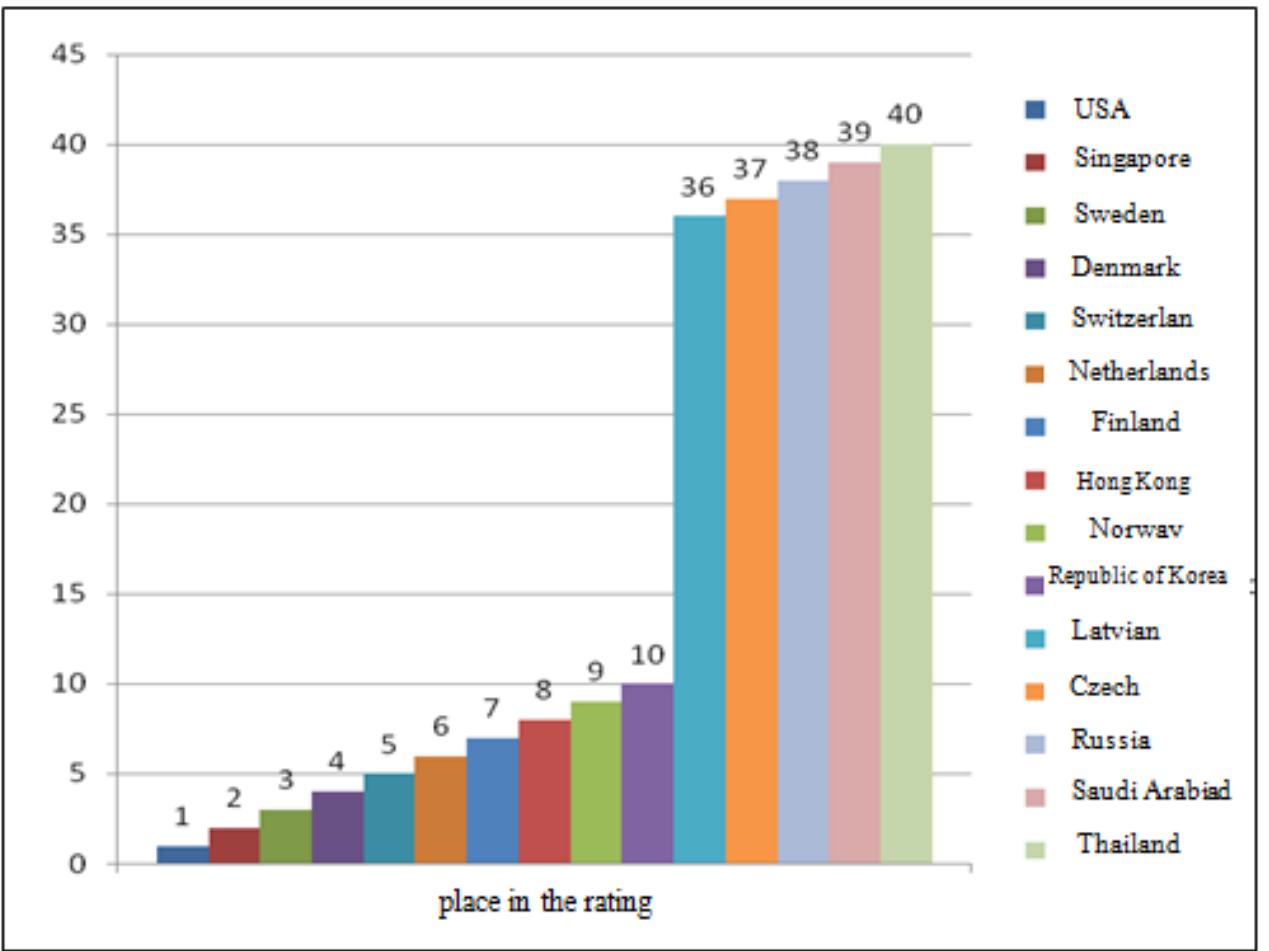

Fig. 1. 2019 digital competitiveness rating

Experts noted that digital technologies such as, for example, 'precision farming' were used by only $3 \%$ of agricultural producers, which indicates a rather low level of application; for example, in the United States, such technologies are used by about $60 \%$ of agricultural producers, and in the EU countries - about $80 \%$ of agricultural producers [8, 9].

Analyzing the process of investing funds associated with implementation of digitalization process in the agricultural sector of the Russian Federation, the following main features can be noted. Considering internal volume of costs associated with the investment of funds, it should be noted that for the period of 2010-2018 there is an increase 
in the volume of expenditures on research and development by $90.1 \%$ (from 9.1 to 17.3 billion rubles); however, as experts note, considering this indicator with the level of comparable prices in 2010, it can be concluded that the corresponding growth was only $3 \%$ (up to 9.4 billion rubles), while in 2015-2017 the dynamics of internal spending on research and development was negative. The growth of internal costs for research and development in 2018 provided only a return to the value of the indicator in 2014 [12].

Considering the volume of investments in agricultural sciences in Russia, it should be noted that at the end of 2018 it amounted to \$ 275 million, comparing these data with the volume of investments in agricultural sciences abroad, we can conclude that this is almost 60 times less than in the United States; at the same time, it should be added that in this country private business provides the bulk of investments, its share in the total cost of agricultural sciences is over $75 \%$, while in the Russian Federation this indicator does not reach the level of $10 \%$ [12].

A slight increase in personnel training costs leads to a shortage of qualified personnel with the necessary level of qualifications in the field of applying knowledge in digital economy. As the research data show, there is a shortage of specialists in the industry with the necessary level of knowledge of information and computer technologies that could contribute to the implementation digital technologies in the agricultural sector; specialists in information and computer technologies in the industry make up only $0.4 \%$ of the total number of all specialists in this field.

Besides, it should be emphasized that a fairly low level of investment in new technologies, in research and development leads to a rather low share of innovative products in the overall structure of agricultural production, and this fact also leads to low rates of its growth in agriculture. The share of innovative products in total production is shown in Figure 2.

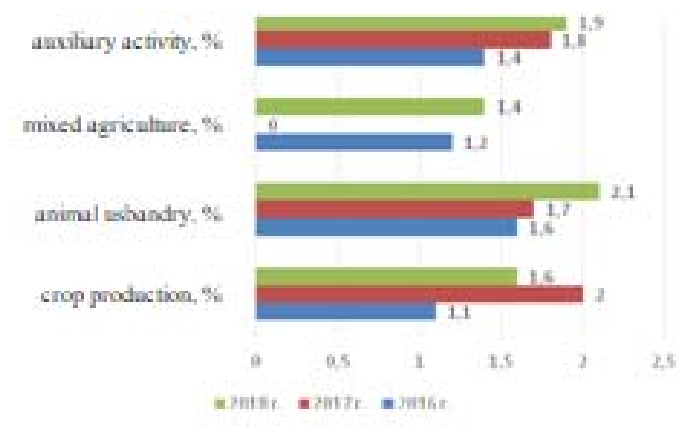

Fig. 2. Share of innovative products in total production.

The movement of industries along the vector of digital transformation towards digital economy is the main driving force behind economic growth of the industry. Russia is in the general trend of using technological solutions and in the same way as in the world and the global industry. At the same time, the use of the main key trends, such as Big Data, machine vision, the Internet of Things, 'smart' farms, sensors and various types of controllers, etc., must find their application in the agro-industrial complex.

According to the analysis of the demand for digital technologies in agriculture [13], the demand for neurotechnologies, artificial intelligence, new production technologies, technologies of virtual and augmented reality is expected in the near future.

The concept of digitalization of agricultural enterprises provides for the implementation of several key activities (Figure 3). 


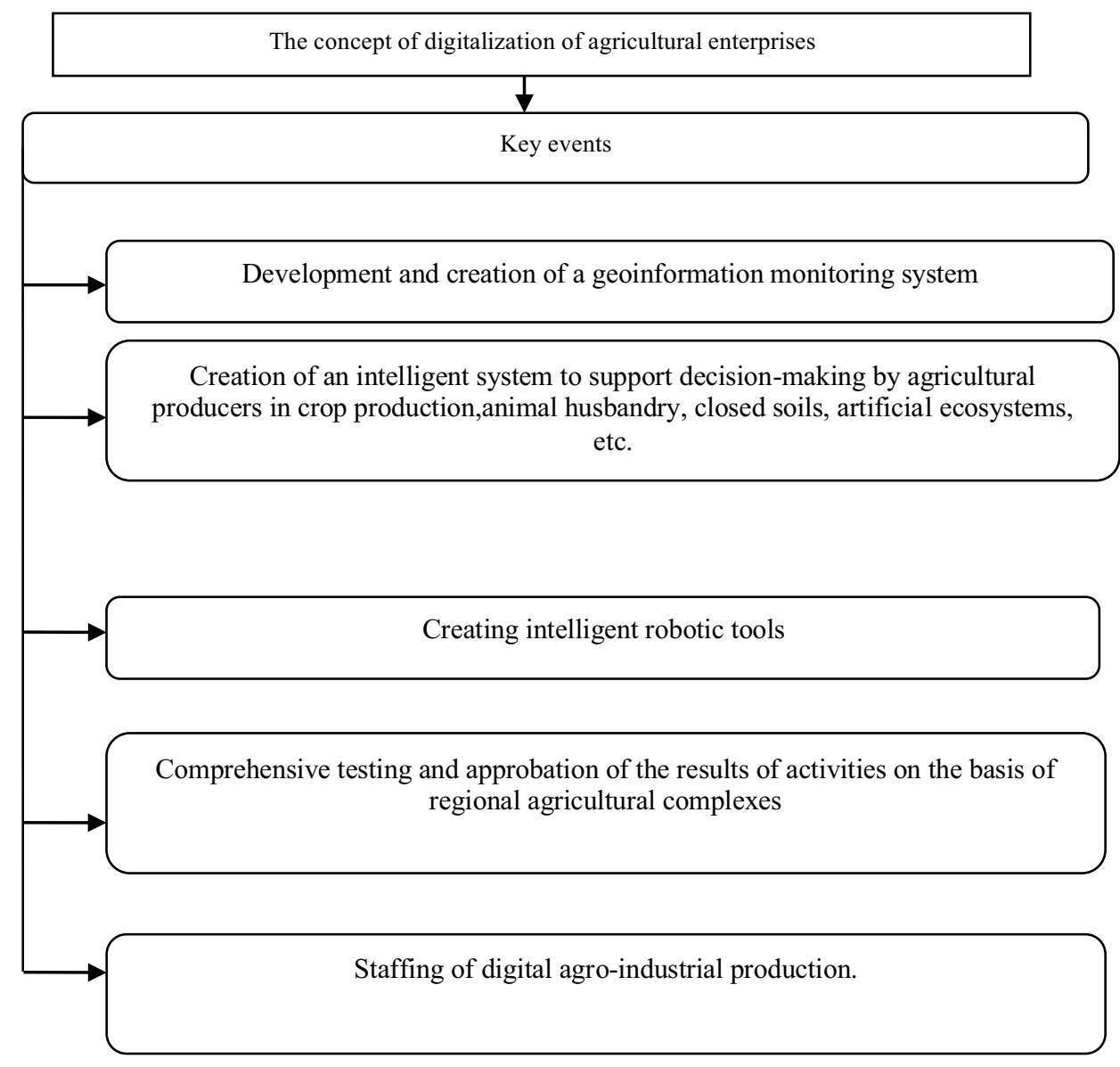

Fig. 3. Key digitalization activities of agro-industrial complex enterprises

Considering implementation of this concept, analyzing the regional use of its individual blocks, it should be noted that such regions as Belgorod, Lipetsk, Samara, Rostov regions, Krasnodar Krai, and the Republic of Tatarstan are actively introducing the implementation of blocks, such as geoinformation monitoring, the use of intelligent robotics, etc. Thus, the Belgorod region became an experiment zone for the National Technological Initiative Program in the field of agriculture. At the regional level, work was carried out on the use of drones in the activities of agricultural enterprises for land inventory, tracking crops, checking the quality of work in the fields, etc.

In order to actively implement the process of introducing digital technologies and platform solutions to agricultural enterprises, the Ministry of Agriculture of the Russian Federation has begun implementing the department project 'Digital Agriculture'. The goal of this project is to provide a technological breakthrough in the agro-industrial complex. Another goal is to increase productivity of agricultural enterprises that actively use achievements of digital economy in their activities, and it is planned to increase productivity twofold by 2024 [14]. The Ministry of Agriculture of the Russian Federation and the developers of this project plan to improve the following targets for the department project 'Digital Agriculture'. 


\section{Conclusion}

Thus, the use of digital technologies in agriculture is going to lead to such positive aspects of the industry functioning as a decrease in the level of production costs; digitalization of the industry is going to contribute to an increase in the financial availability of food products. The process of digital transformation of the industry will lead to a competent, rational use of all natural resources. These activities are going to increase the level of competitiveness of enterprises in the agro-industrial sector, both in the Russian and international markets. As a consequence, this will lead to an increase in the level, as well as biosafety, quality and attractiveness of work in the agro-industrial complex. Development of digitalization of the agro-industrial complex in the regions of the Russian Federation presupposes the use of human resources in this process, and personnel participating in this process must have a list of all the latest competencies necessary to work in new conditions.

The research was carried out within the framework of the state assignment of NRU BelSU FZWG2020-0016 (0624- 2020-0016), the topic of the project 'Fundamental foundations of global territorial and industry specialization in the context of digitalization and technology convergence'

\section{References}

1. Tapscott D. Blockchain Revolution: How the Technology Behind Bitcoin Is Canding Money, Business and the World, London: Penguin, 2016.

2. Gnezdova Yu.V. Development of Russia's digital economy as a factor in increasing global competitiveness. Intellekt. Innovatsii. Investitsii [Intellect. Innovation. Investments]. 5 (2017).

3. Asanov R.K. Formation of 'digital economy' concept in modern science. Sotsialnoekonomicheskiye nauki i gumanitarnye issledovaniya [Socio-economic sciences and humanities research]. 15 (2016).

4. Keshelava A.V., Budanov V.G., Rumyantsev V.Yu. Vvedeniye $v$ tsifrovuyu ekonomiku [Introduction to digital economy]. VNIIG system Publ., (2017).

5. Kapranova L.D. Digital economy in Russia: state and development prospects. Ekonomika. Nalogi. Pravo [Economics. Taxes. Law], 2 (2018).

6. Decree of the President of the Russian Federation dated 09.05.2017 No. 203 'On Strategy for the Development of Information Society in the Russian Federation for 2017-2030'. URL: http://www. kremlin.ru/acts/bank/41919

7. Kolmykova T.S., Merzlyakova E.A. Circular reproduction and environmental innovations in ensuring sustainable growth of the regional economy. Region : sistemy, ekonomika, upravleniye [Region: systems, economics, management]. 3 (46).

8. Monitoring of information society development in the Russian Federation (as of 03.10.2018) - URL: http://www.gks.ru/ free_doc/new_site/figure/anketa1-4.html.

9. Digitalization of agriculture in Russia: stages, results, plans. - URL: https://geometerrussia.ru/a219060-tsifrovizatsiya-selskogohozyajstva.html.

10. Avlasko Z.A., Avlasko P.V. Assessment of effectiveness indicators of investments in scientific innovation and development in the Russian Federation in the conditions of digital economy. Mezhdunarodnyy studencheskiy nauchnyy vestnik [International Student Scientific Bulletin], 4-6, (2018).

11. Belyaev E.V., Shcheglakova A.K. Digital economy as a direction of increasing the efficiency of national economy sectors. Vestnik Ivanovskogo gosudarstvennogo universiteta [Bulletin of the Ivanovo State University]. Series: Economics, 4 (34), (2017). 
12. Innovative development of agro-industrial complex in Russia. Agriculture 4 [Text]: report to XXI Apr. international scientific. conf. on the problems of economic and social development, Moscow (2020).

13. Indicators of digital economy: 2020: statistical collection. Abdrakhmanova G. I., Vishnevsky K.O., Gokhberg L.M. and others; National Research University I60 'Higher School of Economics', Moscow (2020).

14. Digital agriculture in Russia. - URL: https://geometer-russia.ru/a213755- tsifrovoeselskoe-hozyajstvo.htm

15. Kagermann H. Lukas W., Wahlster W. Industrie 4.0: Mit dem Internet der Dinge auf dem Wegzur. 